\title{
Lead Nitrate Induced Testicular Toxicity in Diabetic and Non-Diabetic Rats: Protective Role of Sodium Selenite
}

\author{
Fatma Gokce Apaydin ${ }^{1 *}$, Suna Kalender ${ }^{2}$, Hatice Bas ${ }^{3}$, Filiz Demir $^{4}$ and Yusuf Kalender ${ }^{1}$ \\ ${ }^{I}$ Department of Biology; Faculty of Science; Gazi University; Ankara - Turkey. ${ }^{2}$ Department of Science Education; \\ Faculty of Gazi Education; Gazi University; Ankara - Turkey. ${ }^{3}$ Department of Biology; Faculty of Arts and Science; \\ Bozok University; Yozgat - Turkey. ${ }^{4}$ Department of Biology; Faculty of Arts and Science; Gaziosmanpasa \\ University; Tokat - Turkey
}

\begin{abstract}
Among heavy metals, lead is one of the common pollutants found in the environment and biological system. In the present study, streptozotocin-induced diabetic and normal non-diabetic male Wistar rats were given sodium selenite $(1.0 \mathrm{mg} / \mathrm{kg}$ $\mathrm{bw})$, lead nitrate $(22.5 \mathrm{mg} / \mathrm{kg} \mathrm{bw})$ and sodium selenite plus lead nitrate (1.0 mg/kg+22.5 mg/kg bw, respectively) through gavage. At the end of $4^{\text {th }}$ week, malondialdehyde (MDA) levels, antioxidant enzyme activities [superoxide dismutase (SOD), catalase (CAT), glutathione peroxidase (GPX), glutathione-S-transferase (GST)], and histopathological changes of testes were investigated compared to the control group. No significant differences were observed between the control and sodium selenite treated groups. However, lead nitrate increased the levels of MDA, SOD, CAT, GPX and GST activities compared with the control group in diabetic and non-diabetic rats. Light microscopic analyses revealed that lead nitrate induced numerous histopathological changes in testis tissues of diabetic and non-diabetic rats. In the diabetic and nondiabetic sodium selenite plus lead nitrate treated groups, there were statistically significantly decreased MDA levels and antioxidant enzymes activities and mild pathological changes. As a result, sodium selenite significantly reduced lead nitrate induced testicular toxicity for both diabetic and non-diabetic rats.
\end{abstract}

Key words: Testicular toxicity, Lead nitrate, Sodium selenite, Streptozotocin, Oxidative stress, Histopathology

\section{INTRODUCTION}

Among the toxic chemicals, metals are critical environmental toxicants because they possess bioaccumulative and non-biodegradable properties and are harmful for ecological systems (Sainath et al. 2011). Lead has been one of the most important heavy metals because of its common usage in various industrial products, and therefore, is considered as a serious occupational hazard throughout the world (Ahmed et al. 2012). It is well known that testes are very sensitive to oxidative stress due to its higher polyunsaturated fatty acid content (Acharya et al. 2003). It has been show that lead exposure enhances intracellular ROS production and lipid peroxidation, including tissue damage in animal reproductive systems (Wang and Jia 2009). It has also been reported that lead alters the activities of antioxidant enzymes, such as glutathione peroxidase, catalase and superoxide dismutase in various experimental animals (Flora et al. 2004a; Farmand et al. 2005).

Diabetes mellitus, a metabolic disorder, is characterized by fasting hyperglycemia, deficient insulin secretion or insulin receptor insensitivity (Degirmenci et al. 2005; Chen et al. 2009). It is known that diabetes mellitus affects more than 100 million people worldwide and is considered as one of the five leading causes of death in the world

*Author for correspondence: fguzun@gazi.edu.tr 
(Shanmugam et al. 2011). It has been reported that under diabetic conditions, persistent hyperglycemia may cause high ROS production via glucose auto-oxidation and/or protein glycation in various tissues (Saddala et al. 2013). Also, there are reports on the altered antioxidative enzymes activities and increased lipid peroxidation in animal models and humans with diabetes (Kade et al. 2009a; Schmatz et al. 2012; Prabakaran and Ashokkumar 2013).

Selenium, an essential element, has physiological antioxidant properties and occurs in the body as selenocysteine, a structural component of several enzymes such as glutathione peroxidase (Kade et al. 2009a). It has been shown to exert insulin-like actions on the glucose homeostasis of diabetic rats and has a large number of other biological functions (Kade et al. 2009b). It is known that sodium selenite is a common dietary form of selenium (Shilo et al. 2003). This study determined the possible adverse effects of lead nitrate on the reproductive system of diabetic and non-diabetic male rats and assessed whether these effects could be ameliorate by co-administration with sodium selenite.

\section{MATERIALS AND METHODS}

\begin{abstract}
Animals
Adult male Wistar rats (weighing approximately 200-250 g) were procured from the Gazi University Laboratory Animals Growing and Experimental Research Center. Animals were housed in plastic cages, fed a standard laboratory diet and water ad libitum. Rats were exposed to a $12 \mathrm{~h} \mathrm{light/dark}$ cycle and maintained at $20 \pm 2^{\circ} \mathrm{C}$. They were quarantined for 10 days before beginning the experiment. All the rats were handles in accordance with the standards guide for the care and use of laboratory animals. The Gazi University Committee on the Ethics of Animal Experimentation had approved the animal experiments (Approval number: G.U. ET-11.028).
\end{abstract}

\section{Chemicals}

Lead nitrate (99\% purity), streptozotocin (STZ, 99\% purity) and sodium selenite (99\% purity) were supplied by Sigma-Aldrich (Germany). All other chemicals used were analytical grade and also were obtained from Sigma-Aldrich (Germany).

\section{Animal treatment schedule}

The rats were divided into two main groups: nondiabetic $(n=24)$ and diabetic $(n=24)$. The nondiabetic group was subdivided in four treatment groups, each consisting of six rats: Group 1control rats $(1.0 \mathrm{mg} / \mathrm{kg}$ bw distillated water per day), Group 2-sodium selenite treated rats (1.0 $\mathrm{mg} / \mathrm{kg}$ bw per day in distilled water), Group 3lead nitrate (LN) treated rats $(22.5 \mathrm{mg} / \mathrm{kg}$ bw per day in distilled water), Group 4-sodium selenite plus lead nitrate treated rats $(1.0 \mathrm{mg} / \mathrm{kg}$ bw +22.5 $\mathrm{mg} / \mathrm{kg}$ bw per day, respectively). Diabetes was induced with single intraperitonal injection of STZ $(55 \mathrm{mg} / \mathrm{kg}$, freshly dissolved in $0.1 \mathrm{M}$ sodium citrate buffer, $\mathrm{pH}$ 4.5). Two days after the injection, blood samples were collected via the tail vein and glucose concentrations were measured by a strip-operated blood glucose sensor (Accu-Check Go, Blood glucose marker, Germany). Diabetes was confirmed by blood glucose level $>300 \mathrm{mg} / \mathrm{dL}$ and then subdivided in four treatment groups, each consisting of six rats: Group 5-diabetic control rats $(1.0 \mathrm{mg} / \mathrm{kg}$ bw distilled water per day), Group 6-diabetic sodium selenite treated rats $(1.0 \mathrm{mg} / \mathrm{kg}$ bw per day in distillated water), Group 7-diabetic lead nitrate treated rats $(22.5 \mathrm{mg} / \mathrm{kg}$ bw per day in distillated water), Group 8-diabetic sodium selenite plus lead nitrate treated rats (1.0 $\mathrm{mg} / \mathrm{kg}+22.5 \mathrm{mg} / \mathrm{kg}$ bw per day, respectively).

The oral $\mathrm{LD}_{50}$ of lead nitrate for male rats is 2250 $\mathrm{mg} / \mathrm{kg}$ body weight. We used $1 / 100 \mathrm{LD}_{50}$ of lead nitrate. The doses used in this study were chosen on the basis of previous studies (Kara et al. 2007). The substances were administrated in the morning (between 09:00 and 10:00 h) to non-fasted rats. At the end of the $4^{\text {th }}$ week (28 days) of the treatment, the rats in each group were sacrificed and dissected. The testis tissues were quickly taken to assess the histopathological changes by light microscope examination and to evaluate the antioxidative enzyme activities (SOD, CAT, GPx and GST activities), and malondialdehyde (MDA) levels.

\section{Biochemical Estimation}

The testis tissues were dissected and washed in sodium phosphate buffer $(\mathrm{pH} 7.2)$ and stored at $80^{\circ} \mathrm{C}$ until the analysis. The tissues were homogenized using a Teflon homogenizer (Heidolph Silent Crusher $\mathrm{M}$ ) and then the homogenates were centrifuged at $10,000 \mathrm{~g}$ at $4^{\circ} \mathrm{C}$ for $15 \mathrm{~min}$. MDA content and antioxidant enzyme activities were determined by measuring the 
absorbance of the samples in a spectrophotometer (Shimadzu UV 1700, Kyoto, Japan). Protein content of the supernatant was determined by the method of Lowry et al. (1951) using bovine serum albumin as standard.

\section{Lipid Peroxidation Assay}

MDA content was assayed using the thiobarbituric acid (TBA) test as described by Ohkawa et al. (1979). Absorbance was measured at $532 \mathrm{~nm}$ to determine the MDA content. The specific activity is expressed as $\mathrm{nM} / \mathrm{mg}$ protein of protein.

Measurement of Superoxide Dismutase (SOD), Catalase (CAT), Glutathione Peroxidase (GPX), Glutathione-S-Transferase (GST)

Total SOD activity was determined according to the method described by Marklund and Marklund (1974) by assaying the auto-oxidation and illumination of pyrogallol at $440 \mathrm{~nm}$ for $3 \mathrm{~min}$. The SOD activity is expressed as U/mg protein. CAT activity was measured according to the method described by Aebi (1984) by assaying the hydrolysis of $\mathrm{H}_{2} \mathrm{O}_{2}$ and the resulting decrease in absorbance at $240 \mathrm{~nm}$ over a $3 \mathrm{~min}$ period at $25 \mathrm{C}$. CAT activity is expressed as $\mathrm{mM} / \mathrm{mg}$ protein. GPx activity was measured using $\mathrm{H}_{2} \mathrm{O}_{2}$ as substrate according to the method described by Paglia and Valentine (1967). The reaction was monitored indirectly as the oxidation rate of NADPH at 240 $\mathrm{nm}$ for $3 \mathrm{~min}$. Enzyme activity was expressed as $\mathrm{nM} / \mathrm{mg}$ protein. GST activity was assayed by measuring the formation of GSH (Glutathione) and the 1-chloro-2,4-dinitrobenzene (CDNB) conjugate (Habig et al. 1974). The specific activity of GST is expressed as $\mu \mathrm{M} / \mathrm{mg}$ protein.

\section{Statistical analysis}

The data were analyzed using SPSS 11.0 for Windows. The statistically significance of differences was evaluated by using one-way analysis of variance (ANOVA) followed by Tukey's procedure for multiple comparisons. $\mathrm{P}<0.05$ was considered statistically significant.

\section{Histopathology}

For histopathological examination, testis tissues were dissected and fixed in Bouin solution. Samples were then processed using a graded ethanol series and embedded in paraffin. The paraffin sections were cut into 6-7 $\mu \mathrm{m}$-thick slices and stained with hematoxylin and eosin for histological examination. The sections were viewed and photographed using an Olympus light microscope (Olympus BX51, Tokyo, Japan) with an attached camera (Olympus E-330, Olympus Optical Co. Ltd., Japan).

\section{RESULTS}

\section{Evaluation of biochemical parameters}

At the end of the $4^{\text {th }}$ week, there were no statistically significant changes in MDA levels (Fig.1), SOD, CAT, GPx and GST activities between the sodium selenite treated group compared to the control group and the diabetic sodium selenite treated group compared with the diabetic control group (Table 1).

\section{Malondialdehyde (MDA) levels}

MDA levels in testis tissues was significantly increased in the lead nitrate and sodium selenite plus lead nitrate treated groups compared to the control group, while there were decreased in the sodium selenite plus lead nitrate treated group compared to the only lead nitrate treated group. When diabetic lead nitrate and diabetic sodium selenite plus lead nitrate treated groups compared with the diabetic control group, there were significantly increased in MDA levels. Whereas, a significant decrease in MDA levels was observed in diabetic sodium selenite plus lead nitrate treated group compared to the diabetic LN group. Besides, there was statistically increased in the all diabetic groups compared to non-diabetic groups in MDA levels $(\mathrm{P}<0.05$, Fig. 1).

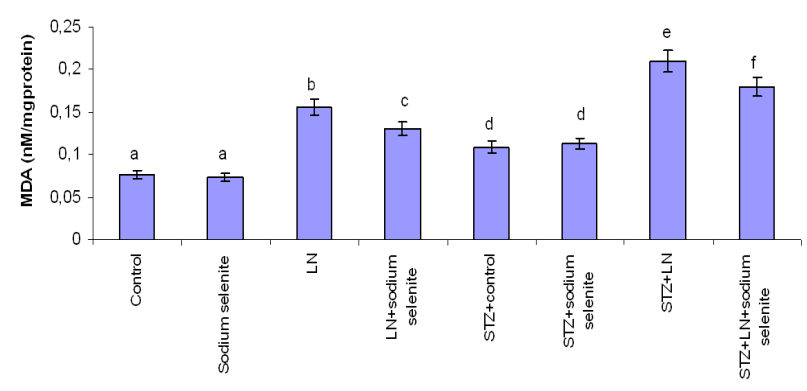

Figure 1 - Effects of subacute treatment of lead nitrate (LN) and sodium selenite on MDA levels ( $\mathrm{nM} / \mathrm{mg}$ protein) in the testis tissues of rats. Each bar represents mean \pm SD of six animals in each group. Columns superscripts with different letters are significantly different. Significance at $\mathrm{P}<0.05$.

\section{Antioxidant enzyme activities}

There was significant increase in the SOD, CAT, GPx and GST activities in the lead nitrate and sodium selenite plus lead nitrate treated groups 
compared to the control group in the testis tissues. However, all enzyme activities were decreased in the sodium selenite plus lead nitrate treated group compared to the only lead nitrate treated group. There were statistically significantly increased in the enzyme activities in the diabetic lead nitrate and diabetic sodium selenite plus lead nitrate treated groups at the end of the $4^{\text {th }}$ week compared to the diabetic control group, while there was decrease in the diabetic sodium selenite plus lead nitrate treated group compared with the diabetic lead nitrate treated group in testis tissues $(\mathrm{P}<0.05$, Table 1).

Table 1 - Effects of lead nitrate (LN) and/or sodium selenite treatment on antioxidant enzymes activities in testis tissues of diabetic (STZ) and nondiabetic male Wistar rats.

\begin{tabular}{lcccc}
\hline Groups & $\begin{array}{c}\text { SOD } \\
(\mathbf{U} / \mathbf{m g} \text { protein) }\end{array}$ & $\begin{array}{c}\text { CAT } \\
(\mathbf{m M} / \mathbf{m g} \text { protein })\end{array}$ & $\begin{array}{c}\text { GPx } \\
(\mathbf{n M} / \mathbf{m g} \text { protein })\end{array}$ & $\begin{array}{c}\text { GST } \\
(\boldsymbol{\mu M} / \mathbf{m g} \text { protein })\end{array}$ \\
\hline Control & $10,130 \pm 1,1095^{\mathrm{a}}$ & $0.719 \pm 0.0428^{\mathrm{a}}$ & $5,684 \pm 0.529^{\mathrm{a}}$ & $0.061 \pm 0.015^{\mathrm{a}}$ \\
Sodium selenite & $10,715 \pm 1,1009^{\mathrm{a}}$ & $0.660 \pm 0.0659^{\mathrm{a}}$ & $5,591 \pm 0.438^{\mathrm{a}}$ & $0.064 \pm 0.010^{\mathrm{a}}$ \\
LN & $19,693 \pm 1,1013^{\mathrm{b}}$ & $1,203 \pm 0.0448^{\mathrm{b}}$ & $12,318 \pm 0.731^{\mathrm{b}}$ & $0.147 \pm 0.011^{\mathrm{b}}$ \\
LN+Sodium selenite & $17,152 \pm 0.991^{\mathrm{c}}$ & $1,036 \pm 0.0614^{\mathrm{c}}$ & $10,092 \pm 0.563^{\mathrm{c}}$ & $0.120 \pm 0.014^{\mathrm{c}}$ \\
STZ+Control & $15,103 \pm 1,0353^{\mathrm{d}}$ & $0.856 \pm 0.0564^{\mathrm{d}}$ & $7,552 \pm 0.537^{\mathrm{d}}$ & $0.082 \pm 0.015^{\mathrm{d}}$ \\
STZ+Sodium selenite & $14,975 \pm 1,2001^{\mathrm{d}}$ & $0.892 \pm 0.0688^{\mathrm{d}}$ & $7,702 \pm 0.532^{\mathrm{d}}$ & $0.090 \pm 0.010^{\mathrm{d}}$ \\
STZ+ LN & $26,80 \pm 1,1116^{\mathrm{e}}$ & $1,530 \pm 0.0518^{\mathrm{e}}$ & $15,553 \pm 0.459^{\mathrm{e}}$ & $0.208 \pm 0.014^{\mathrm{e}}$ \\
STZ+ LN+Sodium selenite & $23,158 \pm 1,0751^{\mathrm{t}}$ & $1,385 \pm 0.0556^{\mathrm{t}}$ & $14,002 \pm 0.692^{\mathrm{t}}$ & $0.181 \pm 0.011^{\mathrm{t}}$ \\
\hline
\end{tabular}

Values are mean \pm SD of six rats in each group. Significance at $\mathrm{P}<0.05$. Within each column, means superscript with different letters are significantly different.

\section{Histopathological changes in the testis tissues}

At the end of the $4^{\text {th }}$ week, the seminiferous tubules and interstitial connective tissue were structurally normal in the control, sodium selenite, diabetic control and diabetic sodium selenite treated groups. However, after 4 weeks of lead nitrate exposure, there were degenerative changes in some of the seminiferous tubules, necrosis in some seminiferous tubules and edema in interstitial tissue was observed. Besides, there were mild degenerative chances in seminiferous tubules in sodium selenite plus lead nitrate treated groups. In addition, there were degenerative changes and edema in diabetic lead nitrate treated group; similarly there were mild degenerative chances and edema in seminiferous tubules in the sodium selenite plus lead nitrate treated group (Fig. 2A-H).
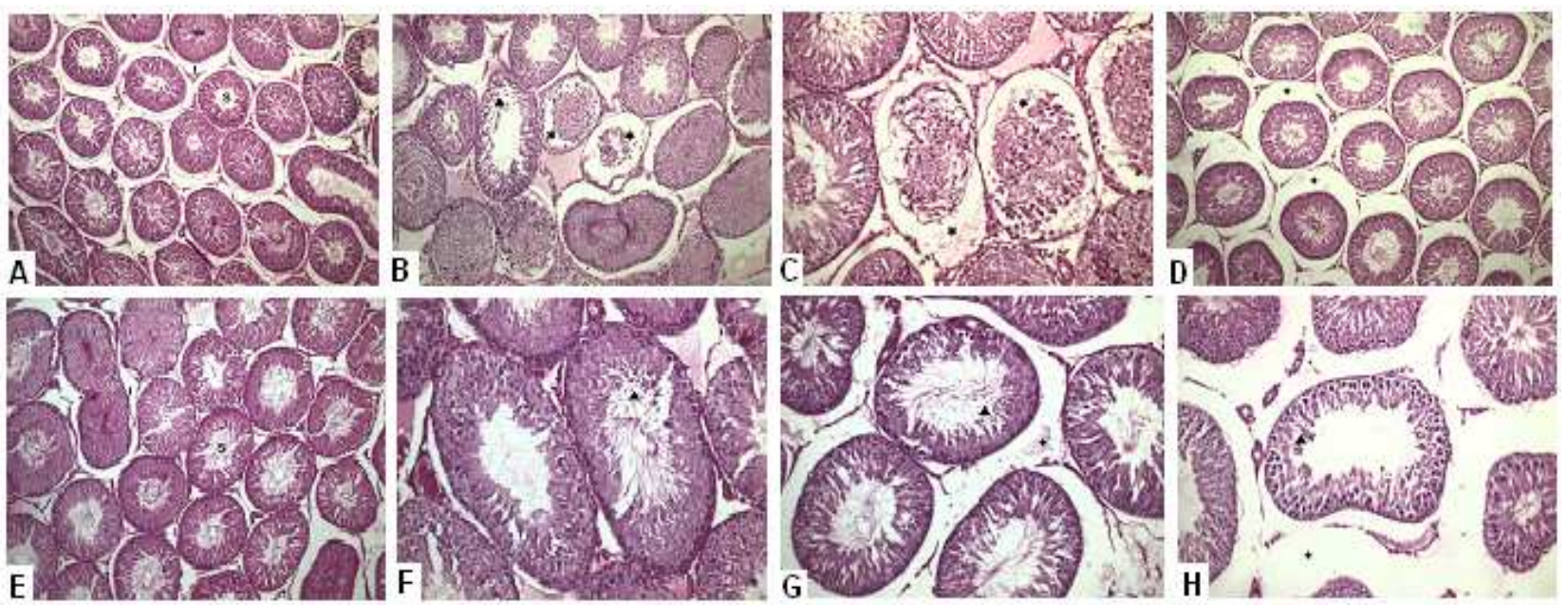

Figure 2 - (A) Testicular section of control rats showing seminiferous tubules (S) and interstitial tissue (I), x100. (B-C) Testicular sections of lead nitrate-treated rats showing necrosis (*) in seminiferous tubules and degenerative changes ( $\mathbf{\Delta})$ x200 and (C) necrosis (*) in seminiferous tubules, x100. Testicular sections of lead nitrate plus sodium selenite treated rats showing (D) edema in intersititial tisues $(\downarrow) \times 200$. (E) Testicular section of diabetic control rats showing seminiferous tubules (S) and interstitial tissue (I), x100 (F-G) Testicular section of diabetic lead nitrate treated rats showing degenerative changes $(\boldsymbol{\Delta})$ in seminiferous tubules, and edema in intersititial tisues $(\downarrow) \times 200$. (H) Testicular sections of diabetic lead nitrate plus sodium selenite treated rats showing degenerative changes $(\boldsymbol{\Delta})$ in seminiferous tubules and edema in intersititial tisues $(\downarrow)$ x 200 . 


\section{DISCUSSION}

Oxidative stress has been considered as a result of alteration antioxidant system (Farmand et al. 2005; Eraslan et al. 2007). It has been reported as one of the important mechanism of toxic effect of lead, like other heavy metals (Flora et al. 2004b). In the previous studies, heavy metal exposure including lead has been shown increase of ROS production in various experimental animal tissues (El-Sokkary et al. 2005; Xia et al. 2010).

It is known that lead causes biochemical and physiological dysfunctions in humans and laboratory animals (Zhang et al. 2010; Kalender et al. 2013). Malondialdehyde (MDA) is a good marker of membrane lipid peroxidation, resulting from the interaction between ROS and cellular membrane (Durak et al. 2010). Lead has been documented to increase the MDA levels in various rat tissues such as liver, brain, kidney and testis (Flora et al. 2004a; El-Sokkary et al. 2005; Sainath et al. 2011). The lipid peroxidation observed as a result of lead administration could be due to the formation of free radicals. In the present study, MDA levels increased in the lead nitrate, sodium selenite plus lead nitrate treated and all diabetic groups. This increase in MDA levels could be due to an increase in free radicals, resulting from the induction of oxidative stress.

Mammalian cells possess non-enzymatic and enzymatic antioxidant defense systems to prevent the oxidative stress that interact with and inactivate ROS (Farmand et al. 2005; Demir et al. 2011). SOD plays an important role in protecting the toxic effects of superoxide radical (Xia et al. 2010; Uzunhisarcıkl1 and Kalender 2011) and catalyzes the conversion of superoxide radicals to hydrogen peroxide (Uzun et al. 2010). CAT is a major antioxidant enzyme having heme as the prosthetic group (Xia et al. 2010) and converts hydrogen peroxide into water (Uzun et al. 2010). Therefore, increase in the SOD and CAT activities has been reported to be due to the first line of defense against free radicals and oxidative stress (Kalender et al. 2013). GPx, a selenoenzyme, plays a major role in the reduction of hydrogen peroxide and hydroperoxide to non-toxic products (Renugadevi and Prabu 2010). GST catalyses the reaction of glutathione conjugation with many xenobiotics and their reactive metabolites; therefore, it produces less toxic forms (Uzun et al. 2010).
The effect on the antioxidant defense systems of cells is defined as the second mechanism for leadinduced oxidative stress (Patra et al. 2011). Oxidative stress and a failure of antioxidant defense system cause several sperm abnormalities and result in infertility. Thus, an imbalance between the ROS generation and scavenging system might be one of the reasons for leadinduced male reproductive toxicity (Sainath et al. 2011). Similarly, in this study SOD, CAT, GPx and GST activities increased in testis tissues of rats treated with lead nitrate. This increased antioxidant activity due to lead nitrate exposure could be a counteracting mechanism adopted to eliminate lead nitrate.

The incidence of diabetes mellitus is increasing worldwide. Although, diabetes-related complications, which cause death, are vascular complications (Afridi et al. 2008). It has been shown that in the various tissues of diabetic rats there were increased lipid peroxidation and altered antioxidant enzymes (Sekeroglu et al. 2000; Duzguner and Kaya 2007; Jin et al. 2008). In this study, results showed that diabetic rats showed improved oxidative stress by enhanced lipid peroxidation and antioxidant enzymes activities. Also, diabetic rats were more susceptible to lead nitrate-induced lipid peroxidation than nondiabetic rats in testis tissues.

It is evident that lead passes through the bloodtestis barrier and induces testicular damage and then they induce oxidative stress, lipid peroxidation and ROS production that damages the biological membranes in the testes, including degeneration of the spermatogenic and Leydig cells (Wang et al. 2006; Sainath et al. 2011), like other environmental toxicants (Dirican and Kalender 2012). Lead can accumulate in the reproductive system, which may lead to a reduced number of spermatogenic cells and has been implicated in the oxidative damage in the laboratory animals (Fahim et al. 2013; Xiang et al. 2013). In the present study, lead nitrate caused several histopathological changes in testis tissues. It demonstrated the presence of diabetesdependent effects on male reproductive system (Navarro-Casado et al. 2010). Similarly to this data, some changes in testis tissues of diabetic rats were also observed. These results showed that the lead and/or diabetes could affect both directly and by increasing the ROS production in testis tissues. It has been shown that selenium has protective effects against diabetes-induced oxidative stress in 
rat models (Kade et al. 2009a; Kade et al. 2009b). Similarly to previous studies, this study also observed ameliorative effects of sodium selenite decreasing the oxidative stress and histopathological changes on testis tissues of lead nitrate treated and/or diabetic rats because of its antioxidant ability. Sodium selenite can indirectly scavenger of ROS such as hydrogen peroxide through increased activity of glutathione peroxides, therefore it may prevent the testicular injury produce by lead nitrate and/or diabetes.

\section{CONCLUSION}

In the present study, even though lead nitrate was given orally at low dose to diabetic and nondiabetic rats, histopathological and enzymatic changes were observed in the rat testis tissues, but none of the rats died during the experimental period. In conclusion, from the results of present investigations, it was evident that lead nitrate caused testicular toxicity, including histopathological changes, LPO and disturbances in antioxidant enzyme activities both diabetic and non-diabetic rats. However, sodium selenite manifested beneficial effects against the testicular toxicity. These results were probably due to generation of ROS, causing damage to cell membranes. Therefore, changes in SOD, CAT, GPx and GST activities in the testis tissue could be a response of the organ to the oxidative stress. Results showed important toxic changes in the diabetic groups, which could be due to oxidative damage in diabetes because oxidative stress has an important role play in the pathogenesis of diabetes. Results showed that Se could, therefore, play a protective role on the toxicity caused by lead.

\section{REFERENCES}

Acharya UR, Rathore RM, Mishra M. Role of vitamin C on lead acetate induced spermatogenesis in Swiss mice. Environ Toxicol Pharmacol. 2003; 13: 9-14.

Aebi H. Catalase in vitro. Methods Enzymol. 1984; 105: 121-126.

Afridi HI., Kazi TG., Kazi N, Jamali MK, Arain MB, Jalbani N, et al. Evaluation of status of toxic metals in biological samples of diabetes mellitus patients. Diabetes Res Clin Pr. 2008; 80: 280-288.
Ahmed YF, Eldebaky HAA, Mahmoud KGhM, Nawito M. Effects of lead exposure on DNA damage and apoptosis in reproductive and vital organs in female rabbits. Global Veterinaria. 2012; 9: 401-408.

Chen YW, Yang CY, Huang CF, Hung DZ, Leung YM, Liu SH. Heavy metals, islet function and diabetes development. Islets. 2009; 1: 169-176.

Degirmenci I, Ustuner MC, Kalender Y, Kalender S, Gunes HV. The effects of acarbose and Rumex patientia L. on ultrastructural and biochemical changes of pancreatic B cells in streptozotocin-induced diabetic rats. J Ethnopharmacol. 2005; 97:555-559

Demir F, Uzun FG, Durak D, Kalender Y. Subacute chlorpyrifos-induced oxidative stress in rat erythrocytes and the protective effects of catechin and quercetin. Pestic Biochem Phys. 2011; 99: 77-81.

Dirican EK, Kalender Y. Dichlorvos induced testicular toxicity in male rats and the protective role of vitamins C and E. Exp Toxicol Pathol. 2012; 64: 821-830.

Durak D, Kalender S, Uzun FG, Demir F, Kalender Y. Mercury chloride-induced oxidative stress and the protective effect of vitamins $\mathrm{C}$ and $\mathrm{E}$ in human erythrocytes in vitro. Afr J Biotechnol. 2010; 9 (4): 488495.

Duzguner V, Kaya S. Effect of zinc on the lipid peroxidation and the antioxidant defense systems of the alloxan-induced diabetic rabbits. Free Radical Bio Med. 2007; 42: 1481-1486.

El-Sokkary GH, Abdel-Rahman GH, Kamel ES. Melatonin protects against lead-induced hepatic and renal toxicity in male rats. Toxicology. 2005; 213: 25-33.

Eraslan G, Saygi S, Essiz D, Aksoy A, Gul H, Macit E. Evaluation of aspect of some oxidative stress parameters using vitamin E, proanthocyanidin and $\mathrm{N}$-acetylcysteine against exposure to cyfluthrin in mice. Pestic Biochem Phys. 2007; 88: 43-49.

Fahim MA, Tariq S, Adeghate E. Vitamin E modifies the ultrastructure of testis and epididymis in mice exposed to lead intoxication. Ann Anat. 2013; 195: 272-277.

Farmand F, Ehdaie A, Roberts CK, Sindhu RK. Leadinduced dysregulation of superoxide dismutases, catalase, glutathione peroxidase, and guanylate cyclase. Environ Res. 2005; 98: 33-39.

Flora SJS, Pande M, Bhadauria S, Kannan GM. Combined administration of taurine and meso 2,3dimercaptosuccinic acid in the treatment of chronic lead intoxication in rats. Hum Exp Toxicol. 2004a; 23: 157166.

Flora SJS, Pande M, Kannan GM, Mehta A. Lead induced oxidative stress and its recovery following coadministration ofmelatonin or n-acetylcysteine during chelation with succimer in male rats. Cell Mol Biol. 2004b; 50: 543-551.

Habig WH, Pabst MJ, Jakoby WB. Glutathione-Stransferases: the first enzymatic step in mercapturic acid formation. J Biol Chem. 1974; 249: 7130-7139. 
Jin L, Xue H-Y, Jin L-J, Li S-Y, Xu Y-P. Antioxidant and pancreas-protective effect of aucubin on rats with streptozotocin-induced diabetes. Eur J Pharmacol. 2008; 582: 162-167.

Kade IJ, Borges VC, Savegnago L, Ibukun EO, Zeni G, Nogueira CW, Rocha JBT. Effect of oral administration of diphenyl diselenide on antioxidant status, and activity of delta aminolevulinic acid dehydratase and isoforms of lactate dehydrogenase, in streptozotocin-induced diabetic rats. Cell Biol Toxicol. 2009a; 25: 415-424

Kade IJ, Nogueira CW, Rocha JBT. Diphenyl diselenide and streptozotocin did not alter cerebral glutamatergic and cholinergic systems but modulate antioxidant status and sodium pump in diabetic rats. Brain Res. 2009b; 1284: 202-211.

Kalender S, Uzun FG, Demir F, Uzunhisarcikli M, Aslanturk A. Mercuric chloride-induced testicular toxicity in rats and the protective role of sodium selenite and vitamin E. Food Chem Toxicol. 2013; 55: 456-462.

Kara H, Cevik A, Konar V, Dayangac A, Yilmaz M. Protective effects of antioxidants against cadmiuminduced oxidative damage in rat testes. Biol Trace Elem Res. 2007; 120: 205-211.

Lowry OH, Rosebrough NJ, Farr AL, Randall RJ. Protein measurement with the Folin phenol reagent. J Biol Chem. 1951; 19: 265.

Marklund S, Marklund G. Involvement of the superoxide anion radical in the autoxidation of pyrogallol and a convenient assay for superoxide dismutase. Eur $J$ Biochem. 1974; 47: 469-474.

Navarro-Casado L, Juncos-Tobarra MA, Chafer-Rudilla M, de Onzono LI, Blazquez-Cabrera JA, MirallesGarcia JM. Effect of experimental diabetes and STZ on male fertility capacity. Study in rats. J Androl. 2010; 31: 584-592.

Ohkawa H, Ohishi N, Yagi K. Assay for lipid peroxides in animal tissues by thiobarbituric acid reaction. Anal Biochem. 1979; 95: 351-358.

Paglia DE. Valentine WN. Studies on the quantitative and qualitative characterization of erythrocytes glutathione peroxidase. J Lab Clin Med. 1967; 70: 158-165.

Patra RC, Rautray AK, Swarup D. Oxidative stress in lead and cadmium toxicity and its amelioration. Vet Med Internat. 2011; 2011: 1-9.

Prabakaran D, Ashokkumar N. Protective effect of esculetin on hyperglycemia-mediated oxidative damage in the hepatic and renal tissues of experimental diabetic rats. Biochimie. 2013; 95: 366-373.

Renugadevi J, Prabu SM. Cadmium-induced hepatotoxicity in rats and the protective effect of naringenin. Exp Toxicol Pathol. 2010; 62: 171-181.

Saddala RR, Thopireddy L, Ganapathi N, Kesireddy SR. Regulation of cardiac oxidative stress and lipid peroxidation in streptozotocin-induced diabetic rats treated with aqueous extract of Pimpinella tirupatiensis tuberous root. Exp Toxicol Pathol. 2013; 65: 15-19.
Sainath SB, Meena R, Supriya Ch, Reddy KP, Reddy PS. Protective role of Centella asiatica on lead-induced oxidative stress and suppressed reproductive health in male rats. Environ Toxicol Pharmacol. 2011; 32: 146154.

Schmatz R, Perreira LB, Stefanello N, Mazzanti C, Spanevello R, Gutierres J, et al. Effects of resveratrol on biomarkers of oxidative stress and on the activity of delta aminolevulinic acid dehydratase in liver and kidney of streptozotocin-induced diabetic rats. Biochimie. 2012; 94: 374-383.

Sekeroglu MR, Sahin H, Dülger H, Algün E. The effect of dietary treatment on erythrocyte lipid peroxidation, superoxide dismutase, glutathione peroxidase and serum lipid peroxidation in patients with type 2 diabetes mellitus. Clin Biochem. 2000; 33: 669-674.

Shanmugam KR, Mallikarjuna K, Nishant K, Kuo CH, Reddy KS. Protective effect of dietary ginger on antioxidant enzymes and oxidative damage in experimental diabetic rat tissues. Food Chem Toxicol. 2011; 124:1436-1442.

Shilo S, Aronis A, Komarnitsky R, Tirosh O. Selenite sensitizes mitochondrial permeability transition pore opening in vitro and in vivo: a possible mechanism for chemo-protection. Biochem J. 2003; 370: 283-290.

Uzun FG, Demir F, Kalender S. Bas H, Kalender Y. Protective effect of catechin and quercetin on chlorpyrifos-induced lung toxicity in male rats. Food Chem Toxicol. 2010; 48: 1714-1720.

Uzunhisarciklı M, Kalender Y. Protective effects of vitamins $\mathrm{C}$ and $\mathrm{E}$ against hepatotoxicity induced by methyl parathion in rats. Ecotox Environ Safe. 2011; 74: 2112-2118.

Wang C, Zhang Y, Liang J, Shan G, Wang Y, Shi Q. Impacts of ascorbic acid and thiamine supplementation at different concentrations on lead toxicity in testis. Clin Chim Acta. 2006; 370: 82-88.

Wang M-Z, Jia X-Y. Low levels of lead exposure induce oxidative damage and DNA damage in the testes of the frog Rana nigromaculata. Ecotoxicology. 2009; 18: 9499.

Xia D, Yu X, Liao S, Shao Q. Mou, H, Ma W. Protective effect of Smilax glabra extract against lead-induced oxidative stress in rats. J Ethnopharmacol. 2010; 130: 414-420.

Xiang D, Zhu J, Jin S, Hu Y, Tan F, Yang W. Expression and function analysis of metallothionein in the testis of Portunus trituberculatus exposed to cadmium. Aquatic Toxicology. 2013; 140-141: 1-10.

Zhang R, Niu Y, Li Y, Zhao C, Song B, Li Y, Zhao Y. Acute toxicity study of the interaction between titanium dioxide nanoparticles and lead acetate in mice. Environ Toxicol Pharmacol. 2010; 30: 52-60.

Received: March 28, 2014; Accepted: June 12, 2014. 